AT - TADBIR

JURNAL ILMIAH MANAJEMEN

Homepage: ojs.uniska.ac.id/attadbir

\title{
Penerapan Metode Yield/Revenue dengan RevPar: Studi Pada Hotel and Convention $X$
}

\author{
Anita Swantari*, Haryo Wicaksono, Filma Festivalia, Heny Ratnaningtyas \\ Sekolah Tinggi Pariwisata Trisakti Jakarta \\ e-mail: anitaswantari@stptrisakti.ac.id
}

\begin{abstract}
This study aims to determine the application of yield/revenue with RevPAR (Revenue Per Available Room). This type of research is quantitative research. The data analysis method in this study uses the trend analysis method. Data sources were obtained from Hotel X\& Conventions in the form of daily hotel reports, revenue management forecast reports and pattern reports from January to December 2018. The results show that Yield/Revenue Management has been implemented well at Hotel X \& Conventions Kelapa Gading in 2018 by making a RevPAR estimate that is close to the actual, with the difference between the estimated data and the actual data being only 5.34\% to 17\%. The highest RevPAR was in August 2018 which was Rp. 585,690,- and the lowest was in February 2018 which was Rp. 474,114. The conclusion of this study is that Hotel $X \&$ Conventions Kelapa Gading has implemented yield/revenue management well in 2018 by carrying out RevPAR estimates which are almost in accordance with the actual, with the difference between the estimated data and the actual data.
\end{abstract}

Keywords: Yield/Revenue Management, RevPar(Revenue Per Available Room)

\begin{abstract}
Abstrak
Penelitian ini bertujuan untuk mengetahui penerapan yield/revenue dengan RevPAR(Revenue Per Available Room). Jenis penelitian ini adalah penelitian kuantitatif. Metode analisis data dalam penelitian ini menggunakan metode analisis trend. Sumber data diperoleh dari Hotel X \& Conventions berupa laporan harian hotel, laporan perkiraan manajemen revenue dan laporan pola dari bulan Januari sampai dengan Desember 2018. Hasil penelitian menunjukkan bahwa Manajemen Yield/Revenue telah diterapkan dengan baik di Hotel X \& Conventions Kelapa Gading pada tahun 2018 dengan melakukan perkiraan RevPAR yang mendekati aktual, dengan selisih data perkiraan dan data aktualnya hanya sebesar 5,34\% hingga 17\%. RevPAR tertinggi terdapat pada bulan Agustus 2018 yaitu sebesar Rp585.690,- dan RevPAR terendah terdapat pada bulan Februari 2018 yaitu sebesar Rp474.114,-. Kesimpulan dari penelitian ini adalah Hotel X \& Conventions Kelapa Gading telah menerapkan manajemen yield/revenue dengan baik pada tahun 2018 dengan melakukan perkiraan RevPAR yang hampir sesuai dengan aktualnya, dengan selisih data perkiraan dan data aktualnya.
\end{abstract}

Kata Kunci: Manajemen Yield/Revenue, RevPar (Revenue Per Available Room) 


\section{PENDAHULUAN}

Semakin tumbuh dan berkembangnya persaingan bisnis di dunia perhotelan sekarang ini, tentunya berbagai cara dilakukan oleh pihak manajemen hotel untuk merebut perhatian kunjungan tamu dan agar para tamu melakukan transaksi atas fasilitas hotel yang tersedia. Tidak dapat dipungkiri bahwa perusahaan dari tahun ke tahun dituntut untuk melakukan perbaikan di segala bidang baik dari segi infrastuktur maupun dari segi sistem kinerjanya baik dari operasional dan juga strategi-strategi untuk mempertahankan kelangsungan hidupnya. Terlebih lagi kini sudah banyak perusahaan yang sejenis bermunculan, sehingga membuat konsumen memiliki banyak pilihan akan apa yang terbaik menurut pendapat mereka.

Hotel X \& Conventions Kelapa Gading merupakan hotel bintang 4 yang terletak di daerah Kelapa Gading-Jakarta Utara pastinya akan selalu memasarkan hotelnya terhadap khalayak di daerah sekitar Kelapa Gading maupun diluar Kelapa Gading. Hotel X \& Conventions Kelapa Gading pun memiliki departemen Revenue (Yielding).

Bagian departemen Revenue (Yielding) pun menggunakan sistem manajemen yield/revenue. Sistem ini memiliki peran penting atas strategi-strategi untuk keberhasilan menarik perhatian tamu dan memaksimalkan Occupancy, Revenue, dan RevPAR di Hotel X \& Conventions Kelapa Gading.

Banyak hotel-hotel yang belum tahu cara mengatur yield/revenue di dunia perhotelan. Pengaturan yield/revenue adalah posisi yang ada pada departemen yang baru dalam dunia perhotelan. Tidak semua hotel memiliki posisi ini. Hingga banyak yang tidak tahu apa dan bagaimana cara bekerjanya. Intinya adalah pengaturan yield/revenue memiliki tujuan untuk memaksimalkan revenue dengan cara melakukan penetapan harga kamar yang dinamis, mengikuti supply dan demand juga memastikan bahwa penetapan harga tersebut mampu memaksimalkan revenue semestinya didapatkan.

Strategi penetapan harga kamar dapat diukur dengan RevPAR (revenue per available room) merupakan metriks yang dapat memberikan informasi mengenai berapa banyak yang didapatkan sebuah hotel dan jumlah revenue yang bisa disetorkan ke rekening bank hotel setiap harinya. RevPAR dihitung berdasarkan total room revenue dibagi total jumlah kamar yang ada, bukan jumlah kamar yang terjual. RevPAR memiliki indikator yang cukup untuk menentukan langkah selanjutnya dalam pengaturan yield/revenue. Ini dikarenakan RevPAR memiliki metriks tetap yang konsisten yang bisa digunakan untuk mengevaluasi kinerja hotel dalam menghadapi persaingan dengan kompetitor.

Penelitian ini bertujuan untuk menganalisis apakah Hotel X \& Conventions Kelapa Gading telah menerapkan yield/revenue dengan RevPAR. Penelitian yang dilakukan oleh Fitriyono \& Thio (2006) menunjukkan bahwa penerapan yield/revenue dengan RevPAR, metode penghitungan pendapatan kamar aktual menjadi lebih nyata dan merata. Hasil penelitian yang dilakukan Ivanov \& Zhechev (2012) menunjukan bahwa penerapan yield/revenue dengan RevPAR akan lebih memahami tingkat hunian dan nilai produktivitas dari total jumlah kamar yang dimiliki hotel.

Penelitian Schwartz, et al (2016) menunjukkan bahwa dengan menghitung yield spengelola dapat menentukan strategi untuk menambah persediaan dan meningkatkan potensi pendapatan hotel. Penelitian yang dilakukan oleh Hermawan (2010) menunjukkan bahwa bahwa penerapan yield/revenue dengan RevPAR 
pengelola dapat mengetahui besarnya pendapatan hotel per kamar dari total ketersediaan kamar yang dimiliki. Wirya dan Widiantara (2019), penelitiannya menunjukkan bahwa penerapan yield/revenue dengan RevPAR akan mudah menghitung nilai penilaian aset jika diperlukan untuk investasi dan jangka panjang. manajemen aset.

Kontribusi dalam penelitian ini adalah sebagai bahan masukan dan pertimbangan bagi manajemen hotel bahwa penerapan yield/revenue dengan Revpar dapat diterapkan dengan optimal agar memaksimalkan pendapatan yang akan diperoleh hotel serta menjadi acuan dalam persaingan antar hotel kompetitor.

\section{KAJIAN PUSTAKA}

Hotel

Hotel adalah suatu perusahaan yang dikelola oleh pemiliknya dengan menyediakan pelayanan makanan, minuman, dan fasilitas kamar untuk tidur kepada orangorang yang sedang melakukan perjalanan dan mampu membayar dengan jumlah yang wajar sesuai dengan pelayanan yang diterima tanpa perjanjian khusus (Sulastiyono, 2011).

Hotel sebagai suatu tempat yang menyediakan fasilitas penginapan untuk masyarakat umum, dan yang dilengkapi satu atau lebih dari layanan berikut: layanan makanan dan minuman, layanan room attendant, layanan berseragam, pencucian linen, dan penggunaan furnitur dan perlengkapan (Kasavana \& Brooks, 1991).

\section{Pendapatan (Revenue)}

Pendapatan (revenue) secara umum sebagai hasil dari suatu perusahaan. Pendapatan adalah darah kehidupan dari suatu perusahaan. Mengingat pentingnya sangat sulit mendefinisikan pendapatan sebagai unsur akuntansi pada dirinya sendiri. Pada dasarnya pendapatan adalah kenaikan laba. Seperti laba pendapatan adalah proses arus penciptaan barang atau jasa oleh suatu perusahaan selama suatu kurun waktu tertentu. Umumnya, pendapatan dinyatakan dalam satuan moneter (uang) (Tuanakotta, 2000).

Pendapatan adalah aliran masuk atau kenaikan lain aktiva suatu badan usaha atau pelunasan utang (atau kombinasi dari keduanya) selama suatu periode yang berasal dari penyerahan atau pembuatan barang, penyerahan jasa, atau dari kegiatan lain yang merupakan kegiatan lain yang merupakan kegiatan utama adan usaha (Baridwan, 1997).

\section{Manajemen Yield/Revenue}

Menurut Hospa (2013), manajemen yield/revenue adalah ilmu yang memaksimalkan pendapatan dengan variabel yang ada yang bertujuan meningkatkan pendapatan dengan memanipulasi harga dimana produk tetap (kamar hotel) dibuat tersedia untuk dijual untuk saat ini dan perkiraan permintaan. Sedangkan menurut Kimes \& Wirtz (2003), manajemen yield/revenue yaitu kemampuan hotel untuk mensegmentasi konsumen dan penentuan harga serta mengontrol inventaris kamar secara berbeda kepada konsumen yang telah disegmentasi dengan mempraktikan beberapa bentuk diskriminasi harga.

$\operatorname{RevPAR}$

RevPAR adalah pengukuran hasil yang berfokus pada pendapatan per kamar yang tersedia (Kasavana \& Brooks, 1991). RevPAR memberikan informasi mengenai penjualan yang dihasilkan untuk setiap kamar yang dimiliki hotel yang dapat dijual kepada tamu Wisyaha (2010). RevPAR (Revenue Per Available Room) merupakan kombinasi dari persentase occupancy dengan ADR (Average Daily Rate) (Schmidgall, 1990).

Berdasarkan atas teori pendukung tersebut maka dirumuskan, apakah manajemen 
yield/revenue telah diterapkan dengan baik di Hotel X \& Conventions Kelapa Gading pada tahun 2018 dengan melakukan perkiraan RevPAR.
Untuk memahami penjelasan di atas, gambar 1 menunjukkan kerangka berpikir logis dari penelitian yang dilakukan ini.

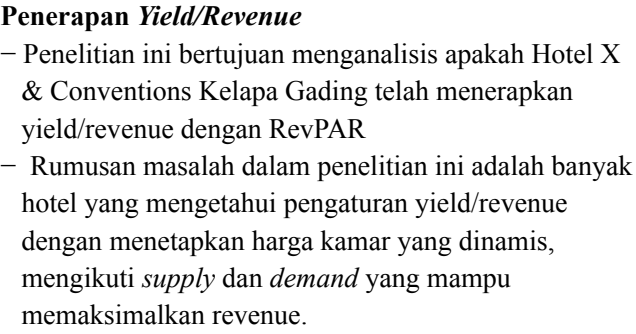

Penelitian Empiris RevPar

- Fitriyono \& Thio (2006), RevPAR lebih

memahami tingkat hunian dan nilai produktivitas dari total jumlah kamar yang dimiliki hotel.

- Hermawan (2010), RevPAR dapat mengetahui

besarnya pendapatan hotel per kamar dari total

ketersediaan kamar yang dimiliki

Kontribusi Penelitian:

Kontribusi dalam penelitian ini adalah dengan penerapan yield/revenue dengan revpar dapat diterapkan dengan optimal agar memaksimalkan pendapatan yang akan diperoleh hotel

\section{Gambar 1. Kerangka Pikir}

Sumber: Hospa (2013)

\section{METODOLOGI PENELITIAN}

\section{Jenis Penelitian}

Jenis penelitian ini adalah penelitian kuantitatif, karena data yang diperoleh berupa angka. Dari angka yang diperoleh akan dianalisis lebih lanjut dalam analisis data. Penelitian ini terdiri atas dua variabel, yaitu yield/revenue dan Revpar.

\section{Sumber data}

Sumber data diperoleh dari Hotel X \& Conventions Kelapa Gading berupa laporan keuangannya. Laporan keuangan dibuat untuk mengetahui kondisi finansial perusahaan secara keseluruhan (Ratnaningtyas, 2021). Laporan keuangan Hotel X \& Conventions untuk menerapkan yield/revenue dengan Revpar meliputi laporan harian hotel (daily on the book), laporan perkiraan manajemen revenue (revenue management budget report) dan laporan pola pemesanan (booking pattern) dari bulan Januari sampai dengan Desember 2018.

\section{Analisis data}

Metode analisis data dalam penelitian ini menggunakan metode analisis trend. Analisis Trend (tendensi posisi) merupakan teknik analisis untuk mengetahui tendesi keadaan keuangan apakah menunjukkan perubahan naik atau mengalami penurunan dalam penerapan pengaturan yield/revenue dengan RevPAR.

Rumus Revpar adalah (1) Average Daily Rate) x 65\% Occupancy; (2) Total Room Revenue/Total Room Available (Kasavana \& Brooks, 1991).

\section{HASIL PENELITIAN}

Hasil penelitian ini akan disajikan dalam bentuk bulanan mulai dari bulan januari sampai dengan bulan desember sebagai berikut. 


\section{Penerapan Yield/Revenue dengan Revpar Bulan Januari 2018}

Berdasarkan tabel 1 pada bulan Januari 2018 dapat diketahui bahwa jumlah kamar yang tersedia adalah 9.517 kamar. Pendapatan kamar aktual pada bulan Januari 2018 sebesar Rp 4.823.766.652,-, sedangkan pendapatan kamar perkiraan sebesar $\mathrm{Rp}$ 5.803.825.741,-, sehingga RevPAR aktual yang diperoleh sebesar Rp 506.858,- dan RevPAR perkiraan yang diperoleh sebesar Rp 609.838,-. Maka dapat diambil kesimpulan bahwa perkiraan RevPAR pada bulan Januari lebih besar dibandingkan aktualnya sebesar Rp 102.980,- atau sebesar $20,32 \%$.

Perkiraan RevPAR pada bulan Januari lebih besar dibandingkan aktualnya disebabkan oleh terjadinya banjir pada tanggal 23 Januari 2018, sehingga memberikan dampak jangka panjang pada jumlah pemesanan kamar di Hotel X \& Conventions Kelapa Gading.

\section{Penerapan Yield/Revenue dengan Revpar Bulan Februari 2018}

Berdasarkan tabel 2 pada bulan Februari 2018 dapat diketahui bahwa jumlah kamar yang tersedia adalah 8.596 kamar. Pendapatan kamar aktual pada bulan Februari 2018 sebesar Rp 4.075.485.553,-, sedangkan pendapatan kamar perkiraan sebesar $\mathrm{Rp}$ 5.345.612.370,-, sehingga RevPAR aktual

Tabel 1. Yield/Revenue Bulan Januari 2018

\begin{tabular}{|l|c|c|}
\hline Details & $\begin{array}{c}\text { Actual Month To } \\
\text { Date }\end{array}$ & January's Budget \\
\hline $\begin{array}{l}\text { Room } \\
\text { Available }\end{array}$ & 9.517 & 9.517 \\
\hline $\begin{array}{l}\text { Room } \\
\text { Occupied }\end{array}$ & 7.158 & 8.487 \\
\hline Room Sold & 7.152 & 8.457 \\
\hline$\%$ Occ & $75,21 \%$ & $89,18 \%$ \\
\hline $\begin{array}{l}\text { Room } \\
\text { Revenue }\end{array}$ & Rp 4.823.766.652 & Rp 5.803.825.741 \\
\hline Revpar & Rp 506.858,- & Rp 609.838,- \\
\hline
\end{tabular}

Sumber: Data diolah, 2021 yang diperoleh sebesar Rp 474,114,- dan RevPAR perkiraan yang diperoleh sebesar Rp 621.872,-. Maka dapat diambil kesimpulan bahwa perkiraan RevPAR pada bulan Februari lebih besar dibandingkan aktualnya sebesar Rp 147.758,- atau sebesar $31,17 \%$.

Bila dibandingkan antara RevPAR aktual pada bulan Januari 2018 dengan RevPAR aktual pada bulan Februari 2018, maka terjadi penurunan sebesar Rp 32.744,- atau sebesar $6,46 \%$. Hal ini disebabkan pertama karena pengaruh selisih jumlah hari dari bulan Januari 2018 (31 hari) dibandingkan bulan Februari 2018 (28 hari) mengalami penurunan sebesar 3 hari. Kedua karena terjadi banjir pada tanggal 9-10 Februari 2018 sehingga memberikan dampak jangka panjang pada jumlah pemesanan kamar di Hotel X \& Conventions Kelapa Gading. Ketiga karena pada tanggal 16 Februari 2018 bertepatan dengan tahun baru Imlek, para konsumen lebih memilih tempat berkumpul bersama keluarga dibandingkan menginap di hotel. Keempat karena jumlah konsumen yang melakukan perpanjangan masa menginap di Hotel X \& Conventions Kelapa Gading pada bulan Februari 2018 mengalami kenaikan dibandingkan dengan bulan Januari 2018, dimana pada bulan Februari 2018 terdapat 339 konsumen, sedangkan pada bulan Januari 2018 terdapat 325 konsumen.

Tabel 2. Yield/Revenue Bulan Februari 2018

\begin{tabular}{|l|c|c|}
\hline Details & $\begin{array}{c}\text { Actual Month To } \\
\text { Date }\end{array}$ & February's Budget \\
\hline $\begin{array}{l}\text { Room } \\
\text { Available }\end{array}$ & 8,596 & 8.596 \\
\hline $\begin{array}{l}\text { Room } \\
\text { Occupied }\end{array}$ & 6.004 & 7.688 \\
\hline Room Sold & 6.004 & 7.674 \\
\hline$\%$ Occ & $69,85 \%$ & $89,44 \%$ \\
\hline $\begin{array}{l}\text { Room } \\
\text { Revenue }\end{array}$ & $\operatorname{Rp~4.075.485.553}$ & $\operatorname{Rp~5.345.612.370~}$ \\
\hline Revpar & $\mathrm{Rp} \mathrm{474.114,--}$ & $\mathrm{Rp} \mathrm{621.872,--}$ \\
\hline
\end{tabular}

Sumber: Data diolah, 2021 


\section{Penerapan Yield/Revenue dengan Revpar Bulan Maret 2018}

Berdasarkan tabel 3 pada bulan Maret 2018 dapat diketahui bahwa jumlah kamar yang tersedia adalah 9.517 kamar. Pendapatan kamar aktual pada bulan Maret 2018 sebesar Rp 5.420.711.333,-, sedangkan pendapatan kamar perkiraan sebesar Rp 5.993.657.891,-, sehingga RevPAR aktual yang diperoleh sebesar Rp 569.582,- dan RevPAR perkiraan yang diperoleh sebesar Rp 629.784,-- Maka dapat diambil kesimpulan bahwa perkiraan RevPAR pada bulan Maret lebih besar dibandingkan aktualnya sebesar Rp 60.202,atau sebesar $10,57 \%$.

Bila dibandingkan antara RevPAR aktual pada bulan Februari 2018 dengan RevPAR aktual pada bulan Maret 2018, maka terjadi kenaikan sebesar Rp 95.468,- atau sebesar 20,14\%. Hal ini disebabkan pertama karena pengaruh selisih jumlah hari dari bulan Februari 2018 (28 hari) dibandingkan bulan Maret 2018 (31 hari) mengalami kenaikan sebesar 3 hari. Kedua karena jumlah konsumen yang melakukan perpanjangan masa menginap di Hotel X \& Conventions Kelapa Gading pada bulan Maret 2018 mengalami kenaikan dibandingkan dengan bulan Februari 2018, dimana pada bulan Maret 2018 terdapat 341 konsumen, sedangkan pada bulan Februari 2018 terdapat 339 konsumen.

Tabel 3. Yield/Revenue Bulan Maret 2018

\begin{tabular}{|l|c|c|}
\hline Details & $\begin{array}{c}\text { Actual Month To } \\
\text { Date }\end{array}$ & March's Budget \\
\hline $\begin{array}{l}\text { Room } \\
\text { Available }\end{array}$ & 9.517 & 9.517 \\
\hline $\begin{array}{l}\text { Room } \\
\text { Occupied }\end{array}$ & 8.129 & 8.600 \\
\hline Room Sold & 8.122 & 8.584 \\
\hline \% Occ & $85,42 \%$ & $90,36 \%$ \\
\hline $\begin{array}{l}\text { Room } \\
\text { Revenue }\end{array}$ & Rp 5.420.711.333 & Rp 5.993.657.891 \\
\hline Revpar & Rp 569.582 & $\operatorname{Rp~629.784~}$ \\
\hline
\end{tabular}

Sumber: Data diolah, 2021

\section{Penerapan Yield/Revenue dengan Revpar Bulan April 2018}

Berdasarkan tabel 4 pada bulan April 2018 dapat diketahui bahwa jumlah kamar yang tersedia adalah 9.210 kamar. Pendapatan kamar aktual pada bulan April 2018 sebesar Rp 5.159.734.297,-, sedangkan pendapatan kamar perkiraan sebesar Rp 5.794.974.340,-, sehingga RevPAR aktual yang diperoleh sebesar Rp 560.232,- dan RevPAR perkiraan yang diperoleh sebesar Rp 629.205,-. Maka dapat diambil kesimpulan bahwa perkiraan RevPAR pada bulan April lebih besar dibandingkan aktualnya sebesar Rp 68.973,atau sebesar $12,31 \%$.

Bila dibandingkan antara RevPAR aktual pada bulan Maret 2018 dengan RevPAR aktual pada bulan April 2018, maka terjadi penurunan sebesar Rp 9.350,- atau sebesar 1,64\%. Hal ini disebabkan karena pengaruh selisih jumlah hari dari bulan Maret 2018 (31 hari) dibandingkan bulan April 2018 (30 hari) mengalami penurunan 1 hari. Selanjutnya karena jumlah konsumen yang melakukan perpanjangan masa menginap di Hotel X \& Conventions Kelapa Gading pada bulan April 2018 mengalami penurunan dibandingkan dengan bulan Maret 2015, dimana pada bulan April 2018 terdapat 326 konsumen, sedangkan pada bulan Maret 2018 terdapat 341 konsumen. Ketiga karena banyak konsumen yang membatalkan pemesanannya karena membatalkan keberangkatannya ke Jakarta, pindah ke hotel lain, dan karena alasan kesehatan.

Tabel 4. Yield/Revenue Bulan April 2018

\begin{tabular}{|l|c|c|}
\hline Details & $\begin{array}{c}\text { Actual Month To } \\
\text { Date }\end{array}$ & April's Budget \\
\hline $\begin{array}{l}\text { Room } \\
\text { Available }\end{array}$ & 9.210 & 9.210 \\
\hline $\begin{array}{l}\text { Room } \\
\text { Occupied }\end{array}$ & 7.657 & 8.317 \\
\hline Room Sold & 7.654 & 8.302 \\
\hline$\%$ Occ & $83,14 \%$ & $90,30 \%$ \\
\hline $\begin{array}{l}\text { Room } \\
\text { Revenue }\end{array}$ & Rp 5.159.734.297 & Rp 5.794.974.340 \\
\hline Revpar & Rp 560.232,-- & Rp 629.205 \\
\hline
\end{tabular}

Sumber: Data diolah, 2021 


\section{Penerapan Yield/Revenue dengan Revpar Bulan Mei 2018}

Berdasarkan tabel 5 pada bulan Mei 2018 dapat diketahui bahwa jumlah kamar yang tersedia adalah 9.517 kamar. Pendapatan kamar aktual pada bulan Mei 2018 sebesar Rp 5.231.943.307,-, sedangkan pendapatan kamar perkiraan sebesar Rp 5.987.943.231,-, sehingga RevPAR aktual yang diperoleh sebesar Rp 549.747,- dan RevPAR perkiraan yang diperoleh sebesar Rp 629.184,-. Maka dapat diambil kesimpulan bahwa perkiraan RevPAR pada bulan Mei lebih besar dibandingkan aktualnya sebesar Rp 79.437,atau sebesar $14,45 \%$.

Bila dibandingkan antara RevPAR aktual pada bulan April 2018 dengan RevPAR aktual pada bulan Mei 2018, maka terjadi penurunan sebesar Rp10.485,- atau sebesar 1,87\%. Hal ini disebabkan pertama karena pengaruh selisih jumlah hari dari bulan April 2018 (30 hari) dibandingkan bulan Mei 2018 (31 hari) mengalami kenaikan sebesar 1 hari. Kedua karena jumlah konsumen yang melakukan perpanjangan masa menginap di Hotel X \& Conventions Kelapa Gading pada bulan Mei 2018 mengalami kenaikan dibandingkan dengan bulan April 2018, dimana pada bulan Mei 2018 terdapat 375 konsumen, sedangkan pada bulan April 2018 terdapat 326 konsumen. Ketiga karena banyak konsumen yang membatalkan pemesanannya karena pindah ke hotel lain.

Tabel 5. Yield/Revenue Bulan Mei 2018

\begin{tabular}{|l|c|c|}
\hline Details & $\begin{array}{c}\text { Actual Month To } \\
\text { Date }\end{array}$ & May's Budget \\
\hline $\begin{array}{l}\text { Room } \\
\text { Available }\end{array}$ & 9.517 & 9.517 \\
\hline $\begin{array}{l}\text { Room } \\
\text { Occupied }\end{array}$ & 7.851 & 8.598 \\
\hline Room Sold & 7.843 & 8.582 \\
\hline \% Occ & $82,49 \%$ & $90,34 \%$ \\
\hline $\begin{array}{l}\text { Room } \\
\text { Revenue }\end{array}$ & Rp 5.231.943.307 & Rp 5.987.943.231 \\
\hline Revpar & Rp 549.747 & Rp 629.184 \\
\hline
\end{tabular}

Sumber: Data diolah, 2021

\section{Penerapan Yield/Revenue dengan Revpar Bulan Juni 2018}

Berdasarkan tabel 6 pada bulan Juni 2018 dapat diketahui bahwa jumlah kamar yang tersedia adalah 9.210 kamar. Pendapatan kamar aktual pada bulan Juni 2018 sebesar Rp 5.091.558.659,-, sedangkan pendapatan kamar perkiraan sebesar Rp 5.650.265.169,-, sehingga RevPAR aktual yang diperoleh sebesar Rp 552.829,- dan RevPAR perkiraan yang diperoleh sebesar Rp 613.492,-. Maka dapat diambil kesimpulan bahwa perkiraan RevPAR pada bulan Juni lebih besar dibandingkan aktualnya sebesar Rp 60.663,atau sebesar 10,97\%.

Bila dibandingkan antara RevPAR aktual pada bulan Mei 2018 dengan RevPAR aktual pada bulan Juni 2018 maka terjadi kenaikan sebesar Rp 3.082,- atau sebesar 0,56\%. Hal ini disebabkan pertama karena pengaruh selisih jumlah hari dari bulan Mei 2018 (31 hari) dibandingkan bulan Juni 2018 (30 hari) mengalami penurunan sebesar 1 hari. Kedua karena jumlah konsumen yang melakukan perpanjangan masa menginap di Hotel X \& Conventions Kelapa Gading pada bulan Juni 2018 mengalami penurunan dibandingkan dengan bulan Mei 2018, dimana pada bulan Juni 2018 terdapat 335 konsumen, sedangkan pada bulan Mei 2018 terdapat 375 konsumen. Ketiga karena banyak perusahaan yang mengadakan acara dan menginap di Hotel X \& Conventions Kelapa Gading.

Tabel 4. Yield/Revenue Bulan Juni 2018

\begin{tabular}{|l|c|c|}
\hline Details & $\begin{array}{c}\text { Actual Month To } \\
\text { Date }\end{array}$ & June's Budget \\
\hline $\begin{array}{l}\text { Room } \\
\text { Available }\end{array}$ & 9.210 & 9.210 \\
\hline $\begin{array}{l}\text { Room } \\
\text { Occupied }\end{array}$ & 7.470 & 8.116 \\
\hline Room Sold & 7.457 & 8.101 \\
\hline$\%$ Occ & $81,11 \%$ & $88,12 \%$ \\
\hline $\begin{array}{l}\text { Room } \\
\text { Revenue }\end{array}$ & Rp 5.091.558.659 & Rp 5.650.265.169 \\
\hline Revpar & $\operatorname{Rp~552.829~}$ & Rp 613.492 \\
\hline
\end{tabular}

Sumber: Data diolah, 2021 


\section{Penerapan Yield/Revenue dengan Revpar Bulan Juli 2018}

Berdasarkan tabel 7 pada bulan Juli 2018 dapat diketahui bahwa jumlah kamar yang tersedia adalah 9.517 kamar. Pendapatan kamar aktual pada bulan Juli 2018 sebesar Rp 4.626.383.152,--, sedangkan pendapatan kamar perkiraan sebesar Rp 5.531.862.618,-, sehingga RevPAR aktual yang diperoleh sebesar Rp 486.118,- dan RevPAR perkiraan yang diperoleh sebesar Rp 581.261,-. Maka dapat diambil kesimpulan bahwa perkiraan RevPAR pada bulan Juli lebih besar dibandingkan aktualnya sebesar Rp 95.143,atau sebesar 19,57\%.

Bila dibandingkan antara RevPAR aktual pada bulan Juni 2018 dengan RevPAR aktual pada bulan Juli 2018, maka terjadi penurunan sebesar Rp 66.711,- atau sebesar 12,07\%. Hal ini disebabkan pertama karena pengaruh selisih jumlah hari dari bulan Juni 2018 (30 hari) dibandingkan bulan Juli 2018 (31 hari) mengalami kenaikan sebesar 1 hari. Kedua karena banyak perorangan, perusahaan, travel agent yang membatalkan menginap di Hotel X \& Conventions Kelapa Gading. Ketiga karena pada bulan Juli 2018 bertepatan pada Hari Raya Idul Fitri, para konsumen lebih memilih tempat berkumpul bersama keluarga dibandingkan menginap/melakukan aktivitas di hotel. Kempat karena jumlah konsumen yang melakukan perpanjangan masa menginap di Hotel X \& Conventions Kelapa Gading pada bulan Juli 2018 mengalami penurunan dibandingkan dengan bulan Juni 2018, dimana

Tabel 7. Yield/Revenue Bulan Juli 2018

\begin{tabular}{|l|c|c|}
\hline Details & $\begin{array}{c}\text { Actual Month To } \\
\text { Date }\end{array}$ & July's Budget \\
\hline $\begin{array}{l}\text { Room } \\
\text { Available }\end{array}$ & 9.517 & 9.517 \\
\hline $\begin{array}{l}\text { Room } \\
\text { Occupied }\end{array}$ & 6.824 & 8.011 \\
\hline Room Sold & 6.815 & 7.995 \\
\hline$\%$ Occ & $71,70 \%$ & $84,18 \%$ \\
\hline $\begin{array}{l}\text { Room } \\
\text { Revenue }\end{array}$ & $\operatorname{Rp~4.626.383.152~}$ & Rp 5.531.862.618 \\
\hline Revpar & $\operatorname{Rp~486.118~}$ & Rp 581.261 \\
\hline
\end{tabular}

Sumber: Data diolah, 2021 pada bulan Juli 2018 terdapat 314 konsumen, sedangkan pada bulan Juni 2018 terdapat 335 konsumen.

\section{Penerapan Yield/Revenue dengan Revpar Bulan Agustus 2018}

Berdasarkan tabel 8 pada bulan Agustus 2018 dapat diketahui bahwa jumlah kamar yang tersedia adalah 9.517 kamar. Pendapatan kamar aktual pada bulan Agustus 2018 sebesar Rp 5.574.007.766,-, sedangkan pendapatan kamar perkiraan sebesar Rp 5.871.492.389,-, sehingga RevPAR aktual yang diperoleh sebesar Rp 585.690,- dan RevPAR perkiraan yang diperoleh sebesar $\mathrm{Rp}$ 616.948,-. Maka dapat diambil kesimpulan bahwa perkiraan RevPAR pada bulan Agustus lebih besar dibandingkan aktualnya sebesar $\mathrm{Rp} 31.258$,atau sebesar 5,34\%.

Bila dibandingkan antara RevPAR aktual pada bulan Juli 2018 dengan RevPAR aktual pada bulan Agustus 2018, maka terjadi kenaikan sebesar Rp 99.572,- atau sebesar $20,48 \%$. Hal ini disebabkan pertama karena tidak ada selisih jumlah hari pada bulan Juli 2018 dengan bulan Agustus 2018 (31 hari). Kedua karena jumlah konsumen yang melakukan perpanjangan masa menginap di Hotel X \& Conventions Kelapa Gading pada bulan Agustus 2018 mengalami kenaikan dibandingkan dengan bulan Juli 2018, dimana pada bulan Agustus 2018 terdapat 356 konsumen, sedangkan pada bulan Juli 2018 terdapat 314 konsumen.

Tabel 8. Yield/Revenue Bulan Agustus 2018

\begin{tabular}{|l|c|c|}
\hline Details & $\begin{array}{c}\text { Actual Month To } \\
\text { Date }\end{array}$ & August's Budget \\
\hline $\begin{array}{l}\text { Room } \\
\text { Available }\end{array}$ & 9.517 & 9.517 \\
\hline $\begin{array}{l}\text { Room } \\
\text { Occupied }\end{array}$ & 8.165 & 8.456 \\
\hline Room Sold & 8.154 & 7.440 \\
\hline$\%$ Occ & $85,79 \%$ & $88,85 \%$ \\
\hline $\begin{array}{l}\text { Room } \\
\text { Revenue }\end{array}$ & Rp 5.574.007.766 & Rp 5.871.492.389 \\
\hline Revpar & Rp 585.690 & Rp 616.948 \\
\hline
\end{tabular}

Sumber: Data diolah, 2021 


\section{Penerapan Yield/Revenue dengan Revpar Bulan September 2018}

Berdasarkan tabel 9 pada bulan September 2018 dapat diketahui bahwa jumlah kamar yang tersedia adalah 9.210 kamar. Pendapatan kamar aktual pada bulan September 2018 sebesar Rp 5.052.934.451,-, sedangkan pendapatan kamar perkiraan sebesar Rp 5.847.584.443,-, $\quad$ sehingga RevPAR aktual yang diperoleh sebesar Rp 548.636,- dan RevPAR perkiraan yang diperoleh sebesar Rp 634.917,-. Maka dapat diambil kesimpulan bahwa perkiraan RevPAR pada bulan September lebih besar dibandingkan aktualnya sebesar Rp86.281,atau sebesar $15,73 \%$.

Bila dibandingkan antara RevPAR aktual pada bulan Agustus 2018 dengan RevPAR aktual pada bulan September 2018, maka terjadi penurunan sebesar Rp 37.054,- atau sebesar 6,33\%. Hal ini disebabkan pertama karena pengaruh selisih jumlah hari dari bulan Agustus 2018 (31 hari) dibandingkan bulan September 2018 mengalami penurunan sebesar 1 hari (30 hari). Kedua karena jumlah konsumen yang melakukan perpanjangan masa menginap di Hotel X \& Conventions Kelapa Gading pada bulan September 2018 mengalami penurunan dibandingkan dengan bulan Agustus 2018, dimana pada bulan September 2018 terdapat 259 konsumen, sedangkan pada bulan Agustus 2018 terdapat 356 konsumen.

Tabel 9. Yield/Revenue Bulan September 2018

\begin{tabular}{|l|c|c|}
\hline Details & $\begin{array}{c}\text { Actual Month To } \\
\text { Date }\end{array}$ & $\begin{array}{c}\text { September's } \\
\text { Budget }\end{array}$ \\
\hline $\begin{array}{l}\text { Room } \\
\text { Available }\end{array}$ & 9.210 & 9.210 \\
\hline $\begin{array}{l}\text { Room } \\
\text { Occupied }\end{array}$ & 7.420 & 8.384 \\
\hline Room Sold & 7.413 & 8.369 \\
\hline \% Occ & $80,56 \%$ & $91,03 \%$ \\
\hline $\begin{array}{l}\text { Room } \\
\text { Revenue }\end{array}$ & Rp 5.052.934.45 & Rp 5.847.584.443 \\
\hline Revpar & Rp 548.636 & $\mathrm{Rp} \mathrm{634.917}$ \\
\hline
\end{tabular}

Sumber: Data diolah, 2021

\section{Penerapan Yield/Revenue dengan Revpar Bulan Oktober 2018}

Berdasarkan tabel 10 pada bulan Oktober 2018 dapat diketahui bahwa jumlah kamar yang tersedia adalah 9.517 kamar. Pendapatan kamar aktual pada bulan Oktober 2018 sebesar Rp 5.489.918.119,-, sedangkan pendapatan kamar perkiraan sebesar Rp 6.056.654.864,-, sehingga RevPAR aktual yang diperoleh sebesar Rp 576.854,- dan RevPAR perkiraan yang diperoleh sebesar $\mathrm{R}$ p636.404,-. Maka dapat diambil kesimpulan bahwa perkiraan RevPAR pada bulan Oktober lebih besar dibandingkan aktualnya sebesar Rp 59.550,- atau sebesar 10,32\%.

Bila dibandingkan antara RevPAR aktual pada bulan September 2018 dengan RevPAR aktual pada bulan Oktober 2018, maka terjadi kenaikan sebesar Rp 28.218,- atau sebesar 5,14\%. Hal ini disebabkan pertama karena pengaruh selisih jumlah hari dari bulan September 2018 (30 hari) dibandingkan bulan Oktober 2018 (31 hari) mengalami kenaikan sebesar 1 hari. Kedua karena jumlah konsumen yang melakukan perpanjangan masa menginap di Hotel X \& Conventions Kelapa Gading pada bulan Oktober 2018 mengalami kenaikan dibandingkan dengan bulan September 2018, dimana pada bulan Oktober 2018 terdapat 274 konsumen, sedangkan pada bulan September 2018 terdapat 259 konsumen.

Tabel 10 Yield/Revenue Bulan Oktober 2018

\begin{tabular}{|l|c|c|}
\hline Details & $\begin{array}{c}\text { Actual Month To } \\
\text { Date }\end{array}$ & October's Budget \\
\hline $\begin{array}{l}\text { Room } \\
\text { Available }\end{array}$ & 9.517 & 9.517 \\
\hline $\begin{array}{l}\text { Room } \\
\text { Occupied }\end{array}$ & 8.195 & 8.681 \\
\hline Room Sold & 8.187 & 8.665 \\
\hline$\%$ Occ & $80,56 \%$ & $91,03 \%$ \\
\hline $\begin{array}{l}\text { Room } \\
\text { Revenue }\end{array}$ & $\operatorname{Rp~5.489.918.119}$ & $\operatorname{Rp~6.056.654.864~}$ \\
\hline Revpar & $\operatorname{Rp~576.854}$ & $\mathrm{Rp} \mathrm{636.404}$ \\
\hline
\end{tabular}

Sumber: Data diolah, 2021 


\section{Penerapan Yield/Revenue dengan Revpar Bulan November 2018}

Berdasarkan tabel pada 11 bulan November 2018 dapat diketahui bahwa jumlah kamar yang tersedia adalah 9.210 kamar. Pendapatan kamar aktual pada bulan November 2018 sebesar Rp 5.391.506.274,-, sedangkan pendapatan kamar perkiraan sebesar Rp 5.848.384.598,-, $\quad$ sehingga RevPAR aktual yang diperoleh sebesar Rp 585.397,- dan RevPAR perkiraan yang diperoleh sebesar Rp 635.004,-. Maka dapat diambil kesimpulan bahwa perkiraan RevPAR pada bulan November lebih besar dibandingkan aktualnya sebesar Rp49.607,atau sebesar $8,47 \%$.

Bila dibandingkan antara RevPAR aktual pada bulan Oktober 2018 dengan RevPAR aktual pada bulan November 2018, maka terjadi kenaikan sebesar Rp8.543,- atau sebesar 1,48\%. Hal ini disebabkan pertama karena pengaruh selisih jumlah hari dari bulan Oktober 2018 (31 hari) dibandingkan bulan November 2018 (30 hari) mengalami penurunan sebesar 1 hari. Kedua karena jumlah konsumen yang melakukan perpanjangan masa menginap di Hotel X \& Conventions Kelapa Gading pada bulan November 2018 mengalami kenaikan dibandingkan dengan bulan Oktober 2018, dimana pada bulan November 2018 terdapat 331 konsumen, sedangkan pada bulan Oktober 2018 terdapat 274 konsumen.

Tabel 11. Yield/Revenue Bulan November 2018

\begin{tabular}{|l|c|c|}
\hline Details & $\begin{array}{c}\text { Actual Month To } \\
\text { Date }\end{array}$ & $\begin{array}{c}\text { November's } \\
\text { Budget }\end{array}$ \\
\hline $\begin{array}{l}\text { Room } \\
\text { Available }\end{array}$ & 9.210 & 9.210 \\
\hline $\begin{array}{l}\text { Room } \\
\text { Occupied }\end{array}$ & 8.132 & 8.386 \\
\hline Room Sold & 8.124 & 8.371 \\
\hline \% Occ & $88,30 \%$ & $91,05 \%$ \\
\hline $\begin{array}{l}\text { Room } \\
\text { Revenue }\end{array}$ & $\operatorname{Rp~5.391.506.274~}$ & $\operatorname{Rp~5.848.384.598~}$ \\
\hline Revpar & $\operatorname{Rp~585.397}$ & $\mathrm{Rp} \mathrm{635.004}$ \\
\hline
\end{tabular}

Sumber: Data diolah, 2021

\section{Penerapan Yield/Revenue dengan Revpar Bulan Desember 2018}

Berdasarkan tabel 12 pada bulan Desember 2018 dapat diketahui bahwa jumlah kamar yang tersedia adalah 9.517 kamar. Pendapatan kamar aktual pada bulan Desember 2018 sebesar Rp 5.191.930.066,-, sedangkan pendapatan kamar perkiraan sebesar Rp 5.798.725.346,-, sehingga RevPAR aktual yang diperoleh sebesar Rp 545.543,- dan RevPAR perkiraan yang diperoleh sebesar Rp 609.302,-. Maka dapat diambil kesimpulan bahwa perkiraan RevPAR pada bulan Desember lebih besar dibandingkan aktualnya sebesar Rp 63.759,atau sebesar $11,69 \%$.

Bila dibandingkan antara RevPAR aktual pada bulan November 2018 dengan RevPAR aktual pada bulan Desember 2018, maka terjadi penurunan sebesar Rp 39.854,- atau sebesar 6,81\%. Hal ini disebabkan pertama karena pengaruh selisih jumlah hari dari bulan November $2018 \quad$ (30 hari) dibandingkan bulan Desember 2018 (31 hari) mengalami kenaikan sebesar 1 hari. Kedua karena jumlah konsumen yang melakukan perpanjangan masa menginap di Hotel X \& Conventions Kelapa Gading pada bulan Desember 2018 mengalami penurunan dibandingkan dengan bulan November 2018, dimana pada bulan Desember 2018 terdapat 291 konsumen, sedangkan pada bulan November 2018 terdapat 331 konsumen.

Tabel 12. Yield/Revenue Bulan Desember 2018

\begin{tabular}{|l|c|c|}
\hline Details & $\begin{array}{c}\text { Actual Month To } \\
\text { Date }\end{array}$ & $\begin{array}{c}\text { December's } \\
\text { Budget }\end{array}$ \\
\hline $\begin{array}{l}\text { Room } \\
\text { Available }\end{array}$ & 9.517 & 9.517 \\
\hline $\begin{array}{l}\text { Room } \\
\text { Occupied }\end{array}$ & 7.773 & 8.343 \\
\hline Room Sold & 7.758 & 8.327 \\
\hline$\%$ Occ & $81,67 \%$ & $87,66 \%$ \\
\hline $\begin{array}{l}\text { Room } \\
\text { Revenue }\end{array}$ & Rp 5.191.930.660 & $\operatorname{Rp~5.798.725.346~}$ \\
\hline Revpar & $\mathrm{Rp} \mathrm{545.543}$ & $\mathrm{Rp} \mathrm{609.302}$ \\
\hline
\end{tabular}

Sumber: Data diolah, 2021 


\section{Hasil Penerapan Yield/Revenue dengan} Revpar Bulan Januari-Desember 2018

Berdasarkan tabel 13 menunjukkan adanya penurunan pendapatan kamar aktual karena adanya banjir pada bulan Januari. Pada bulan berikutnya mengalami penurunan pendapatan kamar aktual karena jumlah hari dalam satu bulan berkurang dan adanya banyak jumlah hari libur dalam satu bulan juga adanya pembatalan pemesanan karena konsumen pindah hotel atau karena sakit. Pada bulan juli adanya penurunan pendapatan kamar aktual karena adanya hari raya Idul Fitri, konsumen lebih senang berkumpul dengan keluarga dibanding menginap di hotel. Kenaikan pendapatan kamar aktual karena jumlah hari dalam satu bulan normal dan banyaknya perusahaan acara dan menginap di Hotel $X \quad \&$ Conventions Kelapa Gading.

Selisih antara data aktual dengan data perkiraan yang ditunjukkan pada gambar 2 menunjukkan bahwa tidak terdapat perbedaan yang signifikan dimana selisih tertinggi terdapat pada bulan Februari 2018 sebesar Rp 147.758,- atau 17\% dan selisih terendah terdapat pada bulan Agustus 2018 sebesar Rp 31.258,- atau 5\%. Hal ini menunjukkan bahwa Manajemen Yield/Revenue telah berperan dengan baik dengan perkiraan RevPAR dan mewujudkan perkiraan tersebut. Meskipun selisi data menunjukkan hasil yang fluktuatif pada setiap bulannya, data setelah bulan Februari menunjukkan trend yang cenderung turun. Hal ini sekaligus menunjukkan bahwa kemampuan RevPar dalam memprediksi tingkat okupansi dan yield yang cukup baik.

Dari hasil analisis penerapan yield/revenue dengan revpar di Hotel X \& Conventions Kelapa Gading, manajer hotel akan lebih memahami tingkat hunian dan nilai produktivitas dari total jumlah kamar yang dimiliki hotel, serta dapat mengetahui besarnya pendapatan hotel per kamar dari total ketersediaan kamar yang dimiliki.

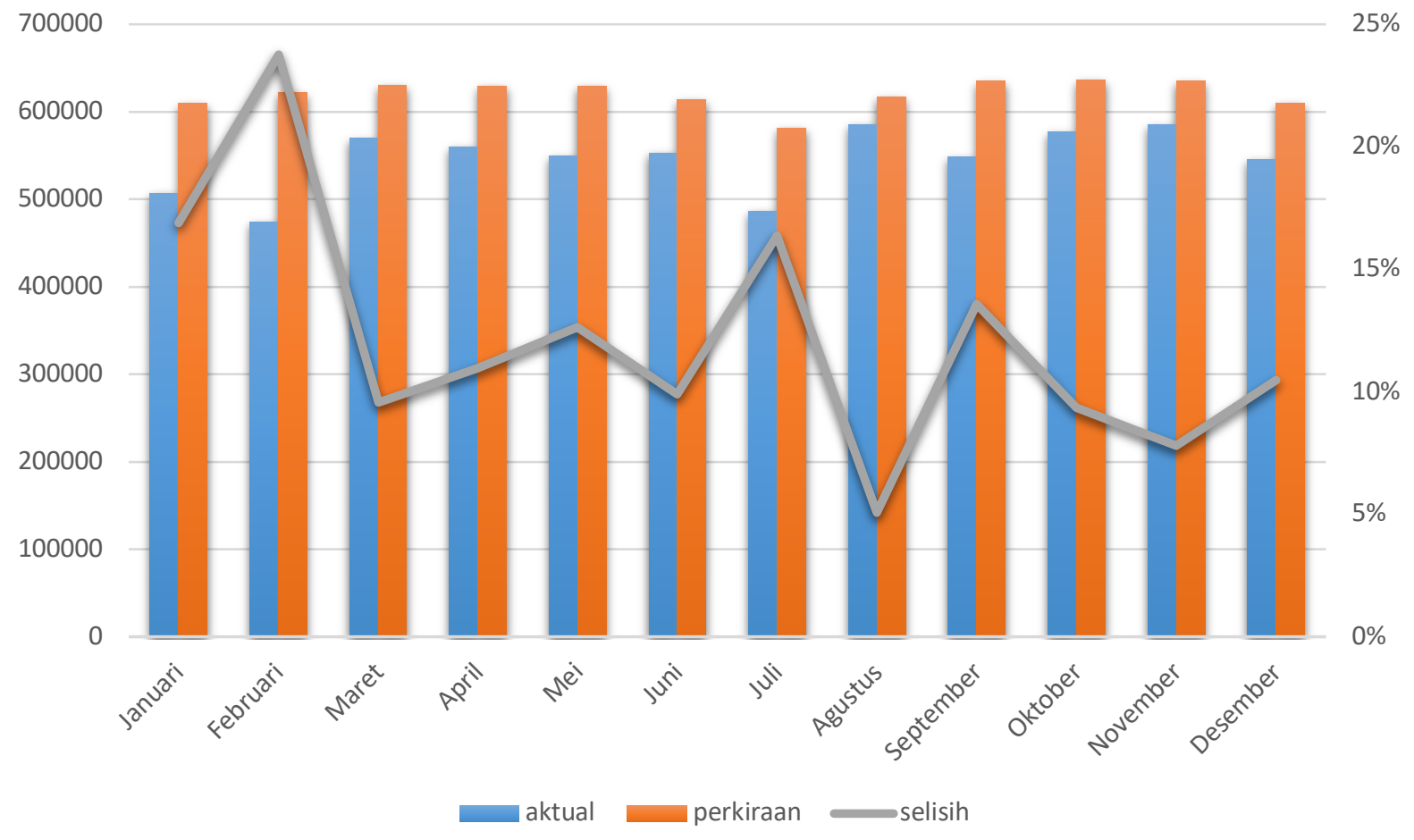

Gambar 2. Hasil Perhitungan RevPar 
Tabel 13. Data Aktual dan Data Perkiraan RevPAR pada Bulan Januari-Desember 2018

\begin{tabular}{|c|c|c|c|c|}
\hline Bulan & Aktual & Perkiraan & Selisih & Persentase \\
\hline Januari & Rp 506.858 & Rp 609.838 & $\mathrm{Rp} 102.980$ & $17 \%$ \\
\hline Februari & Rp 474.114 & $\mathrm{Rp} 621.872$ & Rp 147.758 & $24 \%$ \\
\hline Maret & Rp 569.582 & Rp 629.784 & $\mathrm{Rp} 60.202$ & $10 \%$ \\
\hline April & $\mathrm{Rp} 560.232$ & Rp 629.205 & $\mathrm{Rp} 68.973$ & $11 \%$ \\
\hline Mei & Rp 549.747 & Rp 629.184 & Rp 79.437 & $13 \%$ \\
\hline Juni & Rp 552.829 & Rp 613.492 & $\mathrm{Rp} 60.663$ & $10 \%$ \\
\hline Juli & Rp 486.118 & Rp 581.261 & Rp 95.143 & $16 \%$ \\
\hline Agustus & Rp 585.690 & Rp 616.948 & $\mathrm{Rp} 31.258$ & $5 \%$ \\
\hline September & $\operatorname{Rp} 548.636$ & $\mathrm{Rp} 634.917$ & $\mathrm{Rp} 86.281$ & $14 \%$ \\
\hline Oktober & Rp 576.854 & Rp 636.404 & Rp 59.550 & $9 \%$ \\
\hline November & Rp 585.397 & Rp 635.004 & Rp 49.607 & $8 \%$ \\
\hline Desember & Rp 545.543 & Rp 609.302 & $\mathrm{Rp} 63.759$ & $10 \%$ \\
\hline
\end{tabular}

Sumber: Data diolah, 2021

\section{KESIMPULAN}

\section{Kesimpulan}

Dengan perkembangan hotel yang demikian pesat, membuat cara melihat kinerjanya, Hotel X \& Conventions Kelapa Gading telah menerapkan manajemen yield/revenue dengan baik pada tahun 2018 dengan melakukan perkiraan RevPAR yang hampir sesuai dengan aktualnya, dengan selisih data perkiraan dan data aktualnya. Dengan demikian, manajemen dapat menerapkan RevPar dalam menentukan perubahan harga ke depan dengan menyesuaikan tingkat biaya operasional.

\section{Saran}

Saran dari penelitian ini adalah pihak Hotel X \& Conventions Kelapa Gading harus dapat meningkatkan pelayanan tamu, promosi dan inovasi terhadap produk yang sudah ada dan mengembangkan ketrampilan dan pengetahuan tentang manajemen yield/revenue terutama bagi seluruh karyawan yang berhubungan langsung dengan tamu.

Bagi peneliti lain disarankan untuk menambah indikator penerapan yield/revenue lainnya, selain Revpar masih ada indikator lain tentang strategi penerapan yield/revenue seperti Average Room Rate (ARR), Revenue Per Available Room (RevPAR) dan Gross Operating Profit Per Available Room (GOPPAR).

Studi ini hanya berfokus pada satu objek penelitian yang sangat mungkin mempengaruhi tingkat generalisasi, sehingga peneliti berikutnya juga dapat menerapkan jumlah objek penelitian yang lebih banyak.

\section{DAFTAR PUSTAKA}

Baridwan, Zaki. (1997). Intermediate Accounting. Yogyakarta: BPFE.

Fitriyono, H., \& Thio, S. (2006). Implementasi Yield Management Di Hotel Skala Kecil Dan Menengah Di Surabaya: Investigasi Mengenai Hambatan Dan Faktor Keberhasilan. Jurnal Manajemen Perhotelan, 2(1): 7-17.

Hermawan, B. (2010). Mengelola Pendapatan Kamar Hotel Yang Optimum (Yield Management). Jurnal Media Wisata, 5(2): 26-38.

Hospa. (2013). Revenue Management. Bournemouth: Wentworth Jones.

Ivanov, S., \& Zhechev, V. (2012). Hotel Revenue Management-A Critical 
Literature Review. Tourism, 60(2): 175197.

Kasavana, M. L., \& Brooks, R. (1991). Managing Front Office Operations. Michigan: Educational Institute of American Hotel \& Lodging Association.

Kimes, S.E., \& Wirtz, J. (2003). Has revenue management become acceptable? Findings from an international study on the perceived fairness of rate fences. Journal of Service Research, 6: 125-135.

Ratnaningtyas, H. (2021). Pengaruh Return on Equity, Current Ratio dan Debt to Equity Ratio Terhadap Harga Saham. Jurnal Proaksi, 8(1): 91-102.

Schmidgall, R. S. (1990). Hospitality Industry Managerial Accounting. Michigan: American Hotel \& Motel Association.
Schwartz, Z., Altin, M., \& Singal, M. (2016). Performance measures for strategic revenue management: RevPAR versus GOPPAR. Journal of Revenue and Pricing Management, 16(4): 357-375.

Sulastiyono, A. (2012). Manajemen Penyelenggaraan Hotel. Bandung: Alfabeta.

Tuanakotta, T. M. (2000). Teori Akuntansi. Jakarta: FE UI.

Wirya, I. M. S., \& Widiantara, I. G. A. B. (2019). Strategi Peningkatan Penjualan Kamar Melalui Kegiatan Pemesanan Kamar Dan Yield Management Pada Hotel Grand Hyatt Bali. Jurnal Perhotelan dan Pariwisata, 9(1): 113-125. 